\title{
Communication
}

[Comunicação]

\section{Biopanning the mimotopes of aflatoxin B1 and their immunogenicity}

[Panning de mimotopo aflatoxina B1 e sua imunogenicidade]

\author{
J. Zhou ${ }^{1}$, F. $C h e n^{2}$, J. $L i^{1}$, C. $L i^{1}$, Y. $Q i^{1}$, H. $L i u^{1}$, G. Zhang ${ }^{1}$, A. Wang ${ }^{*}$ \\ ${ }^{1}$ Academy of Life Sciences of Zhengzhou University - Henan - China \\ ${ }^{2}$ Wowen\&infants Hospital of Zhengzhou - Henan - China
}

Aflatoxin B1 (AFB1) is a secondary fungal metabolite, mainly produced by Aspergillus flavus and Aspergillus parasiticus, with a strong toxicity and carcinogenicity, and exists in all kinds of agricultural products universally (Rawal et al., 2010). Governments in many countries have regulatory limits for levels of aflatoxins in agricultural products. Quantitative detection of aflatoxin B1 in agricultural products has become a mandatory measure in international trade (Strosnider et al., 2006).

Due to the common occurrence of aflatoxin contamination, many researchers have tried to reduce aflatoxins and their metabolites in agricultural commodities through various methods. The most direct method is to avoid fungal infection and remove allergic fungal sinusitis in feed crops. In general, the detoxification methods of removing aflatoxins include physical, chemical and biological approaches. The physical treatments include manual or mechanical removal of musty grain, dilution and adsorption. Chemical methods include alkaline method, ammonia treatment and so on. The application of microorganism and enzymes to remove aflatoxins has been reported in recent years (Xiao et al., 2012). Because these methods are subject to detoxification inefficiency with different degrees or might cause nutrient loss, their application is very limited in practical production. It was reported that heat treatment, low temperature storage and fermentation cannot significantly reduce the content of AFM1 in dairy products (Prandini et al., 2009).
AFB1 is a small molecule without immunogenicity, so it must be connected with a carrier protein for animal immunization. In 1977 , Ueno et al. (ano) first reported the exposure of rabbits to AFB1, which were immunized with the complex of bovine serum albumin (BSA) and AFB1. The results showed that toxic responses of the immunized rabbits were decreased significantly. Manifestations were the decline of mortality, serum isocitrate dehydrogenase activity closed to normal level, and normal liver function. The result suggests that the immune method could effectively prevent AFB1 poisoning (Ueno and Chu, 1978). In 2003, Wilkinson et al. reported that chickens, immunized with the complex AFB1 and carrier protein, could be induced to generate neutralizing antibody IgG against AFB1, but not IgA (Wilkinson et al., 2003). Polonelli et al. (ano) reported that cows were immunized with AFB1, which was modified without toxicity, and conjugated with keyhole limpet hemocyanin (KLH). The immunized cows could produce IgG antibody against AFB1, which showed crossreactivity with AFB2, AFG1, AFG2. After immunization, the cows were exposed to AFB1, and had reduced levels of AFM1 in milk production. (Polonelli et al., 2011). These reports showed that immunological methods could prevent AFB1 poisoning or reduce the residues in animal effectively. However, due to that complete antigen may be dissociated and release toxic molecules in vivo, it may pose high risk to humans and animals. In addition, the standard substance of mycotoxin is expensive. Therefore, progress in

Recebido em 25 de fevereiro de 2019

Aceito em 29 de maio de 2019

*Autor para correspondência (corresponding author)

E-mail: pingaw@126.com 
the immunological control of mycotoxin has been very slow until now.

In recent years, the mimic epitope vaccine is becoming one of the hotspots. It has been extensively studied in fields of cancer therapy, anti-allergy, anti-pregnancy and prevention of parasitic diseases. In those studies, some special mimotopes could induce specific antibodies against epitopes (Pande et al., 2010). The mimotopes of deoxynivalenol (DON), ochratoxin A (OTA), corn gibberellic zearalenone (Zen) and AFB1 have been obtained using phage display technology. However, it has not been reported whether the phage-displayed mimotopes of AFB1 have immunogenicity and whether they can be used to control AFB1 poison. If these phagedisplayed mimotopes have the same immunogenicity as AFB1-carrier protein complex, they can be used as a cheap, easy to obtain and safe vaccine to prevent and control AFB1 contamination.

Ph.D-7 Phage Display Peptide Library Kit was purchased from New England Biolabs. Monoclonal antibody against AFB1 and AFB1 were purchased from Sigma Aldrich. Anti-M13 monoclonal antibody conjugated with horseradish peroxidase (HRP) was purchased from Sino Biological Inc. AFB1-OVA were obtained from the Key Laboratory of Animal Immunology, Henan Academy of Agricultural Science. Balb/c mice (Specific pathogen Free, SPF) were purchased from the Experimental Animal Center of College of Medicine, Zhengzhou University. The mice were housed in plastic cages at room temperature $\left(22 \pm 1^{\circ} \mathrm{C}\right)$ and provided with enough commercial pellet diet and water. All experiments were performed in accordance with the institutional ethical guideline of experimental animals.

Biopanning the mimotope of AFB1. $100 \mu$ antiAFB1 mAb $(100 \mu \mathrm{g} / \mathrm{ml})$ was added into each well of 96-well ELISA plate. The plate was incubated overnight at $4^{\circ} \mathrm{C}$. On the following day, the liquid was discarded and the wells were washed six times with TBST (TBS+0.1\% [v/v] of Tween-20), 3 minutes each time. The wells were blocked with blocking buffer $(0.1 \mathrm{M} \mathrm{NaHCO} 3,5 \mathrm{mg} / \mathrm{ml}$ BSA and $0.02 \% \mathrm{NaN}_{3}, \mathrm{pH} 8.6$ ) for 2 hours at $37^{\circ} \mathrm{C}$. original peptide library $\left(2 \times 10^{11} \mathrm{pfu} / \mathrm{ml}\right)$ was added into each well following removal of blocking buffer and incubated for $1 \mathrm{~h}$ at $37^{\circ} \mathrm{C}$. The wells were washed 10 times with TBST (TBS+0.1\% [v/v] Tween-20). The binding phages were isolated according to the following steps: each well was added into $100 \mu \mathrm{l}$ nonspecific buffer (0.2M Glycine-HCl, pH 2.2 and 1mg/ml BSA), shook for $7 \mathrm{~min}$ at room temperature, and treated 10 times with pipette. The elutions were transferred to a fresh micro-centrifuge tube and neutralized with neutralizing buffer $(15 \mu \mathrm{l} 1 \mathrm{M}$ Tris-HCl, pH 9.1). The elution was inoculated into E.coli ER2738 in the mid log phase for phage amplification. The amplified product was used for the following rounds of panning. The panning was carried out in a total of 4 rounds. In order to select high affinity phage and increase the binding specificity gradually, the concentration of coating anti-OTA mAb was gradually reduced to $50 \mu \mathrm{g} / \mathrm{ml}, 25 \mu \mathrm{g} / \mathrm{ml}, 10 \mu \mathrm{g} / \mathrm{ml}$ and the concentration of Tween-20 in TBST was raised to $0.25 \%, 0.5 \%$, $0.5 \%$, respectively. Other conditions remained unchanged.

Screening positive mimotopes of AFB1 by PhageELISA. The phages from the four panning eluant $(1 \mu 1)$ were serially diluted and mixed with $200 \mu 1$ bacterial culture in mid log phase in a centrifuge tube, incubated for $5 \mathrm{~min}$ at room temperature. The mixture was transferred into the top agar at $45^{\circ} \mathrm{C}$, mixed quickly and poured on the IPTG/X-gal (isopropyl- $\beta$-d-thiogalactoside/5-bro-mo-4-

chloro-3-indoly-beta-D-galac toside) plate. Five minutes later, the plate was inverted and incubated at $37^{\circ} \mathrm{C}$ overnight. The next day, twenty blue plaques from the plates were selected randomly and separately inoculated into E.coli ER2738 culture in the mid log phase, incubated at $37^{\circ} \mathrm{C}$, $220 \mathrm{rpm}$ for $5 \mathrm{~h}$. The culture was transferred to a centrifuge tube and centrifuged at $10000 \mathrm{rpm}$ for $20 \mathrm{~min}$ at $4^{\circ} \mathrm{C}$. Eighty percent of the supernatant was added to a fresh tube, blended with $1 / 6$ volume of $\mathrm{PEG} / \mathrm{NaCl}$ and incubated at $4^{\circ} \mathrm{C}$ overnight to precipitate phages. The next day, the tube was centrifuged at $10000 \mathrm{rpm}$ for $20 \mathrm{~min}$ at $4^{\circ} \mathrm{C}$. The supernatant was discarded, and the phage pellet was suspended in TBS $(500 \mu \mathrm{l})$ and blended with $1 / 6$ volume of $\mathrm{PEG} / \mathrm{NaCl}$, and incubated in ice for $1 \mathrm{~h}$, then spun at $10000 \mathrm{rpm}$ for $10 \mathrm{~min}$ at $4^{\circ} \mathrm{C}$. The supernatant was discarded, and the pellet resuspended in TBS $(500 \mu 1)$.

A 96-well ELISA plate was coated with $10 \mu \mathrm{g} / \mathrm{ml}$ anti-AFB $1 \mathrm{mAb}\left(50 \mu \mathrm{l}\right.$ per well), incubated at $4{ }^{\circ} \mathrm{C}$ overnight. The wells were blocked with $5 \%$ 
porcine serum $\left(200 \mu 1\right.$ per well) at $4^{\circ} \mathrm{C}$ overnight, and then washed 6 times with TBST (TBS+0.5\% [v/v] Tween-20). Fifty microliters of amplified phages were added into each well, followed by incubation at $37^{\circ} \mathrm{C}$ for $1 \mathrm{~h}$, washed 6 times with TBST. Fifty microliters of anti-M13mAb HRP conjugate diluted 1:1000 was added into each well and incubated at $37^{\circ} \mathrm{C}$ for $1 \mathrm{~h}$. After washing 6 times with TBST, TMB substrate was added into each well and incubated at $37^{\circ} \mathrm{C}$ for $5 \mathrm{~min}$. The reaction was stopped by $2 \mathrm{~mol} / \mathrm{L} \mathrm{H}_{2} \mathrm{SO}_{4}$. The absorbance at $450 \mathrm{~nm}$ was determined by microplate reader. The original phage library was used as positive control and TBST as blank control. Phages with $\mathrm{P} / \mathrm{N}>2.1$ were judged to be positive clones.

Identification of the specificity of positive phages by competitive ELISA (cELISA). ELISA plate was coated with $100 \mu \mathrm{l}$ anti-AFB1 mAb $(10 \mu \mathrm{g} / \mathrm{ml})$, incubated at $4^{\circ} \mathrm{C}$ overnight, then blocked with $5 \%$ porcine serum overnight. AFB1 standard $(50 \mu 1,100 \mathrm{ng} / \mathrm{ml})$ and equal volumes of positive phages with appropriate dilution were added into each well. After incubation at $37^{\circ} \mathrm{C}$ for 40min, the plate was washed 6 times with TBST. Fifty microliters of anti-M13mAb HRP conjugate was added into each well and incubated at $37^{\circ} \mathrm{C}$ for 40min. The plate was washed 6 times with TBST. TMB substrate was added into each well and the reaction was stopped by $2 \mathrm{~mol} / \mathrm{L} \mathrm{H}_{2} \mathrm{SO}_{4}$. The absorbance at $450 \mathrm{~nm}$ was determined by an ELISA plate reader. The group of original phage library was used as positive control. The group, added with anti-AFB1 $\mathrm{mAb}$ and the original phage library, was used as negative control, and the group added with anti-AFB1 $\mathrm{mAb}$ and TBST was used as blank control. The phages inhibited by AFB1 standard were picked to be positive phages of AFB1, and sequenced by GENEWIZ Inc (Beijing, China).

Immunization of Balb/c mice with specific positive phage. The $4-6$ weeks old female Balb/c mice were divided into three groups randomly. The mice of experimental groups were immunized with high dose $\left(10^{12} \mathrm{pfu}\right)$ and low dose $\left(10^{10} \mathrm{pfu}\right)$ of positive phages namely $\mathrm{P} 10$, respectively. The control group was immunized with PBS. The $\mathrm{Balb} / \mathrm{c}$ mice were immunized by multiple site subcutaneous injection, and anti-serum collected after immunization two times.

Detection of the antibody titer using positive phage as coating antigen. The wells were coated with positive phages $(50 \mu 1$ per well), which were diluted with CBS buffer. After incubation at $4^{\circ} \mathrm{C}$ for $12 \mathrm{~h}$, the wells were blocked with $5 \%$ porcine serum at $4^{\circ} \mathrm{C}$ for $12 \mathrm{~h}$. Anti-serums of the mice were diluted with PBS two-fold serially and added into each well. PBS-immunized mouse serum was used as control group, and non-immunized mouse serum was used as negative control (NC). The group, added with PBS only, was designed as blank control (BC). The plate was incubated at $37^{\circ} \mathrm{C}$ for $40 \mathrm{~min}$. The plate was washed 3 times. Rabbit anti-mouse secondary antibody was added into each well and incubated at $37^{\circ} \mathrm{C}$ for $40 \mathrm{~min}$. The color reaction was conducted with TMB substrate and stopped by $2 \mathrm{~mol} / \mathrm{L} \mathrm{H}_{2} \mathrm{SO}_{4}$. The absorbance at $450 \mathrm{~nm}$ was determined by microplate reader.

Detection of antibody titer using AFB1-OVA as coating antigen. The wells $(50 \mu l$ per well) were coated with $8 \mu \mathrm{g} / \mathrm{ml}$ AFB1-OVA at $4^{\circ} \mathrm{C}$ for $12 \mathrm{~h}$, which were diluted with CBS buffer. The antibody titer of the mice was determined by the same method as described above. Biopanning the mimotopes of AFB1. A total of four rounds of affinity panning were performed in this study. In order to select high affinity phage and increase the binding specificity gradually, the concentration of coated anti-AFB1 mAb was reduced gradually, and the concentration of Tween-20 in TBST raised gradually at the same time. The result was shown in Table 1. Enrichment of phages was observed after each round of biopanning.

Identification of antigen mimotopes by ELISA. After four rounds of biopanning, eighteen blue phage plaques were randomly picked from the plates and identified by Phage-ELISA. Among them, fourteen phage plaques were positive clones, and four phage plaques were negative clones. thirteen phages could be inhibited to bind anti-AFB $1 \mathrm{mAb}$ by AFB1 standard in competitive ELISA, named P1, P2, P4, P5, P8, P10, P11, P12, $\mathrm{P} 13, \mathrm{P} 14, \mathrm{P} 15, \mathrm{P} 16$ and $\mathrm{P} 17$, respectively. The results are shown in Figure 1. 
Table 1. Enrichment of phages in 4 rounds of biopanning

\begin{tabular}{lllll} 
Round & Antibody $(\mu \mathrm{g} \cdot \mathrm{ml}-1)$ & $\begin{array}{l}\text { Phage input }(\mathrm{pfu} \cdot \mathrm{ml}- \\
1)\end{array}$ & Phage output $(\mathrm{pfu} \cdot \mathrm{ml}-1)$ & $\begin{array}{l}\text { Recovery rate } \\
(\%) 1\end{array}$ \\
\hline 1 & 100 & $2 \times 10^{11}$ & $1.06 \times 10^{5}$ & $5.3 \times 10^{-7}$ \\
2 & 50 & $2 \times 10^{11}$ & $3.40 \times 10^{5}$ & $1.7 \times 10^{-6}$ \\
3 & 25 & $2 \times 10^{11}$ & $1.00 \times 10^{7}$ & $5.0 \times 10^{-5}$ \\
4 & 10 & $2 \times 10^{11}$ & $2.00 \times 10^{7}$ & $1.0 \times 10^{-4}$
\end{tabular}

${ }^{1}$ The phage recovery rate of each round was obtained via dividing the phage output number by phage input number.

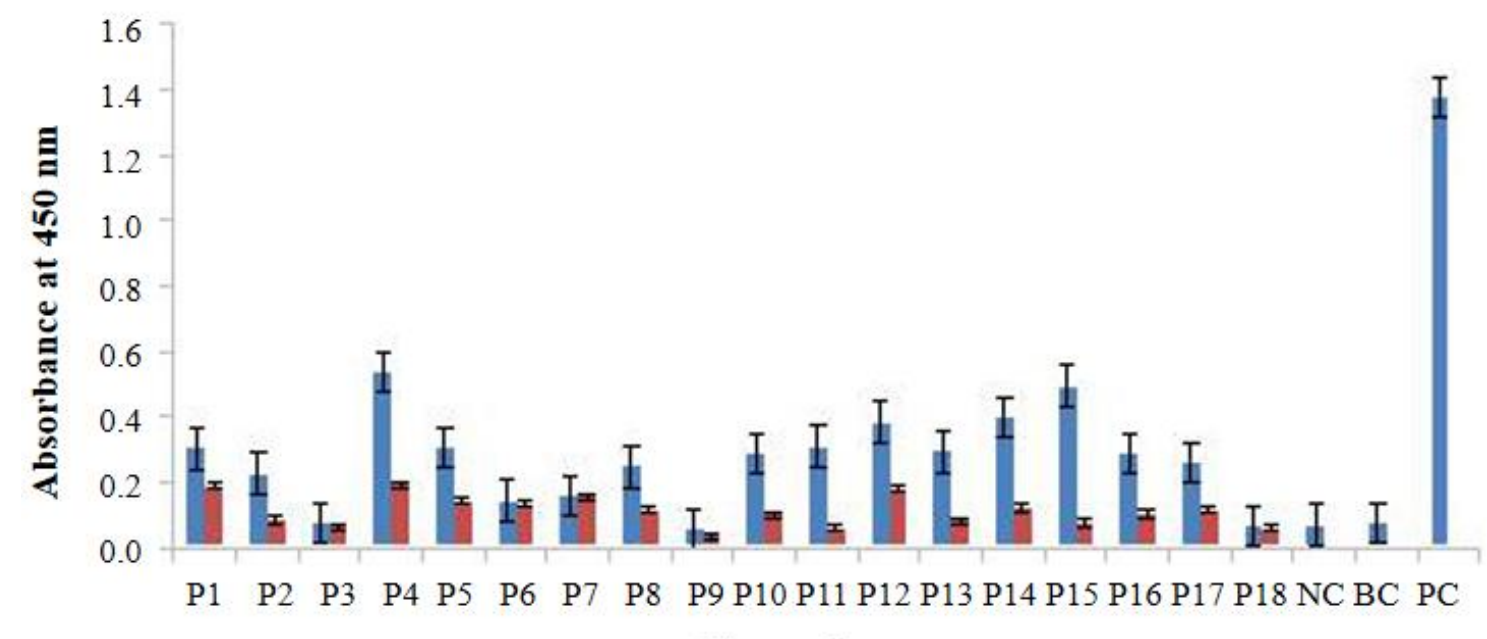

\section{Phage clone}

Figure 1. Screening of positive clones by phage ELISA( $\square)$ and competitive ELISA( $\square)$. NC, negative control; BC, blank control; PC, positive control. Fourteen phage plaques ( P1, P2, P4, P5, P7, P8, P10, $\mathrm{P} 11, \mathrm{P} 12, \mathrm{P} 13, \mathrm{P} 14, \mathrm{P} 15, \mathrm{P} 16$ and P17) were positive clones, and four phage plaques ( 3 , P6, P9 and P18) were negative clones. Thirteen phages (P1, P2, P4, P5, P8, P10, P11, P12, P13, P14, P15, P16 and $\mathrm{P} 17$ ) could be inhibited to bind anti-AFB1 mAb by AFB1 standard in competitive ELISA.

Amino acid sequence of mimotopes. The sequencing results were showed in Table 2 . Twelve of the 13 positive clones display the correct sequences except that the clone named P2 have some mutations. P1, P4, P10, P12, P14, P15 and P17 have the same amino acid sequences YRRHEKD, and they were expected to be the same strain. The competitive inhibition of positive phages. P5, P8, P11, P13 were just slightly inhibited by AFB1 standard at the concentration of $500 \mathrm{ng} / \mathrm{ml}$. The inhibition curves of P10 were drawn as Figure 2, showing the greatest inhibition to AFB1.

Table 2. The amino acid sequences of positive clones

\begin{tabular}{ll}
\hline Positive phage & amino acid sequences \\
\hline P1 、P4、P10、P12、P14、P15、P17 & YRRHEKD \\
P5 & RKRSDDT \\
P8 & TGSSPLL \\
P11 & SFAQIQI \\
P13 & YHMGPAN \\
P16 & FARANAA \\
\hline
\end{tabular}




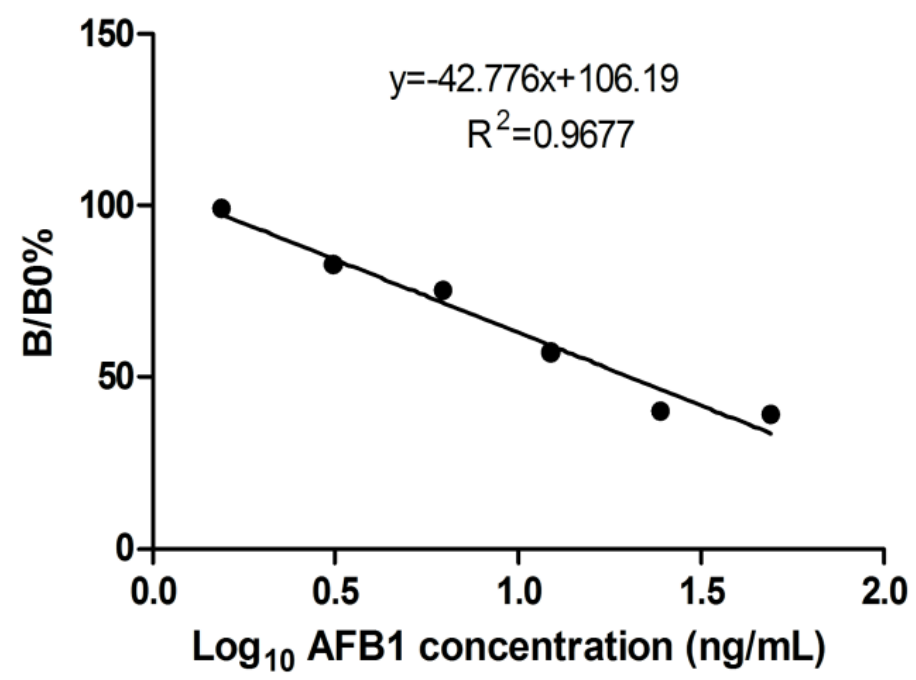

Figure 2. The indirect competitive ELISA curve of positive phage P10. IC50 was $20.41 \mathrm{ng} / \mathrm{ml}$, linear range was $1.5-50 \mathrm{ng} / \mathrm{ml}$.

Antibody titer in mice immunized with mimotop. In this study, we used P10 and AFB1-OVA as coating antigen, respectively, to detect antibodies of immunized mice. From Table 3 and Table 4, we can see that the mice produced large amounts of specific antibodies for P10 after they were immunized with phage-displayed mimotope two times. The antibody titer of high dose $\left(10^{12}\right.$ pfu/per) group reached 1:25600 and low dose $\left(10^{10} \mathrm{pfu} / \mathrm{per}\right)$ group 1:6400. To further determine the specificity of the antibodies induced, the antibody titer of the high dose group was detected using AFB1-OVA as coating antigen. As showed in Table 5, the antibody titer of the immunized mice by P10 (10 12 pfu/per) could reach 1:1600.

Table 3. Detection of high dose group of antibodies in mice by ELISA

\begin{tabular}{|c|c|c|c|c|c|c|c|c|c|}
\hline \multirow{2}{*}{ No. } & \multicolumn{9}{|c|}{ Anti-serum Dilution } \\
\hline & $1: 800$ & $1: 1600$ & $1: 3200$ & $1: 6400$ & $1: 12800$ & $1: 25600$ & PBS & $\mathrm{NC}$ & $\mathrm{BC}$ \\
\hline 1 & 2.282 & 2.229 & 1.404 & 0.941 & 0.569 & 0.384 & 0.170 & 0.070 & 0.057 \\
\hline 2 & 2.488 & 1.487 & 0.961 & 0.669 & 0.336 & 0.224 & 0.093 & 0.070 & 0.060 \\
\hline 3 & 2.439 & 1.478 & 1.214 & 0.640 & 0.321 & 0.245 & 0.083 & 0.070 & 0.059 \\
\hline
\end{tabular}

Table 4. Detection of low dose group of antibodies in mice by ELISA

\begin{tabular}{|c|c|c|c|c|c|c|c|c|c|}
\hline \multirow{2}{*}{ No. } & \multicolumn{9}{|c|}{ Anti-serum Dilution } \\
\hline & $1: 800$ & $1: 1600$ & $1: 3200$ & $1: 6400$ & $1: 12800$ & $1: 25600$ & PBS & $\mathrm{NC}$ & $\mathrm{BC}$ \\
\hline 1 & 0.770 & 0.641 & 0.209 & 0.190 & 0.104 & 0.079 & 0.170 & 0.070 & 0.057 \\
\hline 2 & 0.963 & 0.466 & 0.278 & 0.190 & 0.118 & 0.083 & 0.093 & 0.070 & 0.060 \\
\hline 3 & 0.721 & 0.494 & 0.237 & 0.181 & 0.107 & 0.082 & 0.083 & 0.070 & 0.059 \\
\hline
\end{tabular}

Table 5. Detection of high dose group of antibodies in mice by ELISA

\begin{tabular}{llllllll}
\hline \multirow{2}{*}{ No. } & \multicolumn{7}{l}{ Anti-serum Dilution } \\
\cline { 2 - 8 } & $1: 100$ & $1: 200$ & $1: 400$ & $1: 800$ & $1: 1600$ & BC & NC \\
\hline 1 & 1.580 & 0.965 & 0.612 & 0.505 & 0.251 & 0.049 & 0.090 \\
2 & 0.883 & 0.359 & 0.142 & NT & NT & 0.050 & 0.089 \\
3 & 0.531 & 0.221 & 0.135 & NT & NT & 0.048 & 0.091 \\
\hline
\end{tabular}

\section{NT: No Test}


Analysis of the amino acid sequences of phagedisplayed mimotopes. Six different phage clones were obtained in this study. Their sequences are different from each other, and the sequences reported previously. The amino acid sequences of P10 are different from the sequences ("-THRNW-") obtained by Wang et al. (2013), wherein only one amino acid is the same at position 4. The mimotopes of AFB1, reported by Liu et al (2012) are rich in tryptophan (W) and histidine $(\mathrm{H})$, and contains one or more amino acids with benzene circle (Y-tyrosine, Wtryptophan, F-phenylalanine). Thirumala-Devi et al. (2001) used two anti-AFB1 monoclonal antibodies (MAb 13 and MAb 24) as the targets for clone selection and obtained the amino acid sequences containing "PW" and "YMD", respectively. Phage P10, obtained in this study, contains $\mathrm{H}$ and $\mathrm{Y}$, but the position of the amino acids is different. It is possible that binding is mainly associated with the spatial structure of mimotopes. We conclude that the amino acids Y, $\mathrm{H}$ are critical for phage-displayed peptides to replace antigens.

The immunogenicity of mimotope. Balb/c mice were immunized with the positive phage P10 directly. M13 can stimulate the mice to produce large amounts of peculiar antibodies against M13 after being immunized twice. The result indicated that M13 phages have a good immunogenicity (Table 3 and 4). All mice can produce the specific antibodies for AFB1 after immunization with the positive phage P10 twice. The titer of number 1 mouse reached 1:1600 and the others reached 1:400. The results showed that immunization with mimotopes could induce the bodies to produce specific antibodies against AFB1. How to further improve the antibody titer needs a deeper investigation and more comprehensive experiments.

In our study, we found that the mimotopes of AFB1 have immunogenicity. The amplification and purification of phages compared with the synthesis of complete antigen are rapid, easy, and convenient. In addition, they do not involve toxins. It is a promising protection method. When phages are used to immunize animals the adjuvant is not necessary. Phage is an ideal vaccine vector. We will continue to do more comprehensive tests to obtain more specific and sensitive mimotopes of AFB1.

Keywords: aflatoxin B1, mimotope, vaccine, immunogenicity

\section{RESUMO}

Utilizando um anticorpo monoclonal contra a aflatoxina B1 (AFB1) como ligante, foi identificado um mimotopo específico de aflatoxina B1 após se realizarem quatro ciclos de seleção biológica de 7-peptídeos aleatórios em biblioteca de fago exibida. O mimotopo é denominado P10, e sua sequência de aminoácidos é YRRHEKD. O soro imunológico de ratos Balb/c imunizados com P10 foi especificamente ligado à aflatoxina B1-albumina, indicando que o anticorpo era específico ao AFB1. Esses resultados sugerem que é possível desenvolver a vacina baseada em mimotopo associado à toxina.

Palavras-chave: aflatoxina B1, mimotopo, vacina, imunogenicidade

\section{ACKNOWLEDGEMENTS}

This study was funded by the National Science and Technology Support Program (grant no. 2014BAD13B05). This work was supported by grants from the National Key Research and Development Program of China (2019YFC1604501).

\section{REFERENCES}

LIU, R.; XU, L.; QIU, X. et al. An Immunoassay for determining aflatoxin B1 using a recombinant phage as a nontoxic coating conjugate. J. Food Saf., v.32, p.318-325, 2012.

PANDE, J.; SZEWCZYK, M.M.; GROVER, A.K. Phage display: concept, innovations, applications and future. Biotechnol. Adv., v.28, p.849-858, 2010. 
POLONELLI, L.; GIOVATI, L.; MAGLIANI, W. et al. Vaccination of lactating dairy cows for the prevention of aflatoxin B1 carry over in milk. PLOS One, v.6, p.e.26777, 2011.

PRANDINI, A.; TANSINI, G.; SIGOLO, S. et al. On the occurrence of aflatoxin M1 in milk and dairy products. Food Chem. Toxicol., v.47, p.984991, 2009.

RAWAL， S.; KIM, J.I.E.; COULOMBE, R. Aflatoxin B1 in poultry: toxicology, metabolism and prevention. Res. Vet. Sci., v.89, p.325-331, 2010.

STROSNIDER, H.; AZZIZ-BAUMGARTNER, E.; BANZIGER, M. et al. Public health strategies for reducing exposure aflatoxin in developing countries. Environ. Health Perspect., v.114, p.1898-1903, 2006.
THIRUMALA-DEVI, K.; MILLER, J.S.; REDDY, G. et al. Phage-displayed peptides that mimic aflatoxin B1 in serological reactivity. $J$. Appl. Microbio., v.90, p.330-336, 2001.

UENO, I.; CHU, F.S. Modification of hepatotoxic effects of aflatoxin B1 in rabbits by immunization. Experientia, v.34, p.85-86, 1978.

WANG, Y.R.; WANG, H.; LI, P.W. et al. Phagedisplayed peptide that mimics aflatoxins and its application in immunoassay. J. Agric. Food Chem., v.61, p.2426-2433, 2013.

WILKINSON, J.; ROOD, D.; MINIOR, D. et al. Immune response to a mucosally administered aflatoxin B1 vaccine. Poult. Sci., v.82, p.15651572, 2003.

XIAO, J.X.; ZHANG, Y.; HUANG, G.Q. et al. Research progress on the removal of aflatoxins. J. Food Saf. Q., v.3, p.395-399, 2012 